\title{
Chitin synthesis in Fusarium graminearum and its inhibition by edifenphos (Hinosan)
}

\author{
Peter R. Binks, ${ }^{1 *}$ Geoffrey D. Robson, ${ }^{1}$ Michael W. Goosey, ${ }^{2}$ Anne Humphreys ${ }^{3}$ and \\ ANTHONY P. J. TRINCI ${ }^{1}$ \\ ${ }^{1}$ Microbiology Research Group, Department of Cell and Structural Biology, Stopford Building, University of Manchester, \\ Manchester M13 9PT, UK \\ ${ }^{2}$ Shell Research Ltd, Sittingbourne, Kent ME9 8AG, UK \\ ${ }^{3}$ Department of Applied Biology, Liverpool Polytechnic, Byrom Street, Liverpool L3 3AL, UK
}

(Received 20 July 1990; revised 1 October 1990; accepted 7 November 1990)

\begin{abstract}
Membrane-bound chitin synthase from Fusarium graminearum A3/5 had a pH optimum of 6.5, an apparent temperature optimum of $30^{\circ} \mathrm{C}$ and an apparent $K_{\mathrm{m}}$ for UDP- $N$-acetylglucosamine (UDP-GlcNAc) of $2.5 \mathrm{mM}$. Digitonin-solubilized chitin synthase had a lower (about $25 \%$ of the original activity) and more variable activity than the membrane-bound chitin synthase from which it was prepared. The activity of solubilized chitin synthase was stabilized by incorporating Allosamidin (a chitinase inhibitor) into the reaction mixture, and an approximately 3.6-fold increase in activity was observed when the reaction mixture contained dimyristoylphosphatidylcholine. Concentrations of the organophosphorus fungicide edifenphos (Hinosan) up to $25 \mu \mathrm{M}$ had no effect on the in vitro activity of membrane-bound chitin synthase, but between 25 and $145 \mu \mathrm{M}$, chitin synthase activity decreased with increase in fungicide concentration. Edifenphos caused non-competitive inhibition of chitin synthase activity with an apparent $K_{\mathrm{i}}$ of $50 \mu \mathrm{M}$. Membrane-bound chitin synthase preparations from cultures of $F$. graminearum grown in $250 \mu \mathrm{M}$-edifenphos had a much lower in vitro activity than preparations from cultures grown in the absence of the fungicide. Pre-growth of $F$. graminearum in $250 \mu \mathrm{M}$ (but not $80 \mu \mathrm{M}$ ) edifenphos also caused a reduction in incorporation of $\left[{ }^{3} \mathrm{H} \mid\right.$ GleNAc into chitin in vivo (washed biomass was incubated in [ $\left.{ }^{3} \mathrm{H}\right]$ GlcNAc-containing medium lacking fungicide).
\end{abstract}

\section{Introduction}

Edifenphos (Hinosan; $O$-ethyl-S,S-diphenylphosphorodithioate) was marketed in 1968 to control Pyricularia oryzae on rice (Scheinpflug \& Jung, 1968), but there is still some uncertainty about its mode of action. Maeda $e t$ al. (1970) reported that iprobenfos (a related organophosphorus fungicide) inhibited incorporation of $\left[{ }^{14} \mathrm{C}\right]$ glucosamine into the cell wall of $P$. oryzae and they suggested that the fungicide inhibited chitin synthesis either directly, by inhibiting chitin synthase (EC 2.4.1.16), or indirectly, by altering membrane (cytoplasmic) permeability; chitin synthase in fungi is a membraneassociated enzyme (Gooday \& de Rousset-Hall, 1975).

Although edifenphos and iprobenfos increased the permeability of membranes of $P$. oryzae (De Waard, 1974), iprobenfos had no effect on the membrane permeability of Aspergillus nidulans (Craig \& Peberdy, $1983 a$ ). There are also contradictory reports of the effects of edifenphos and iprobenfos on phosphatidylcholine synthesis; for example Akatsuka et al. (1977), Kodama et al. (1979) and Ross \& Brady (1985) reported that organophosphorus fungicides inhibited phosphatidylcholine synthesis, but Craig \& Peberdy (1983b) found that iprobenfos did not affect the phosphatidylcholine content of $A$. nidulans. Recently, Wiebe et al. (1990) showed that, at low concentrations (up to $246 \mu \mathrm{M}$ ), edifenphos acted as a paramorphogen (Tatum et al., 1949), increasing branching of Fusarium graminearum A3/5, but not affecting its specific growth rate. They also showed that a concentration of edifenphos $(123 \mu \mathrm{M})$ which did not affect specific growth rate caused a decrease in the phosphatidylcholine content of $F$. graminearum, and that this decrease was still observed when the fungus was grown in the presence of choline. This result, together with the observations of Kodama et al. (1980), suggests that edifenphos inhibits both the Kennedy (Kennedy \& Weiss, 1956) and Greenberg (Bremner \& Greenberg, 1961) pathways for phosphatidylcholine synthesis. 
Edifenphos and iprobenfos have been reported to inhibit the incorporation of $\left[{ }^{14} \mathrm{C}\right]$ glucosamine into mycelia of $P$. oryzae (De Waard, 1974), and both fungicides have been shown to inhibit the activity of chitin synthase preparations from various fungi (Kodama et al., 1980; Craig \& Peberdy, $1983 a$; Leighton et al., 1981). However, Brillinger (1979) found that chitin synthase from Coprinus cinereus was not inhibited by iprobenfos, and De Waard (1974) reported that Pythium ultimum, an Oomycete with walls containing cellulose but not chitin, was inhibited by both edifenphos and iprobenfos.

The present work was undertaken to determine the primary site of action of edifenphos in $F$. graminearum, and in particular to determine if chitin synthase is inhibited by the fungicide directly and/or indirectly through a primary effect on membrane phospholipid composition.

\section{Methods}

Organism and medium. Fusarium graminearum Schwabe strain A3/5 was obtained from Mr T. W. Naylor, Marlow Foods, Billingham, UK. The defined medium of Vogel (1956) was used with glucose $\left(10 \mathrm{~g}^{-1}\right)$ as the carbon source instead of sucrose. Vogel's mineral salts solution was prepared at $\times 50$ final concentration, sterilized by membrane filtration ( $0.22 \mu \mathrm{m}$ pore diameter, Whatman), and added to the glucose solution, which was sterilized by autoclaving at $121^{\circ} \mathrm{C}$ for $15 \mathrm{~min}$. When necessary, the medium was solidified with $15 \mathrm{~g} \mathrm{l}^{-1}$ agar (Taiyo technical grade; Davis Gelatine).

Chemicals. Edifenphos (Hinosan; $O$-ethyl-S,S-diphenylphosphorodithioate) was kindly provided by Imperial Chemical Industries PLC, Jealott's Hill Research Station, Bracknell, UK and contained 30\% $(w / v)$ of active ingredient (allowance for this is made when fungicide concentrations are given in Results). UDP- $N$-acetyl-D- $-{ }^{14} \mathrm{Clgluco}-$ samine (UDP- $\left[{ }^{14} \mathrm{C}\right] \mathrm{GlcNAc}$ ) and $N$-acetyl-D- $\left[{ }^{3} \mathrm{H}\right]$ glucosamine $\left(\left[{ }^{3} \mathrm{H}\right] \mathrm{GlcNAc}\right)$ were obtained from Amersham. Allosamidin was kindly provided by Professor Akita Isogal, University of Tokyo, Japan. Other chemicals were of Analar grade and, unless stated otherwise, were obtained from BDH.

Cultural conditions. Batch cultures were grown in $50 \mathrm{ml}$ volumes in $250 \mathrm{ml}$ Nephlos flasks (Trinci, 1972). Each flask was inoculated with 1 $\mathrm{ml}$ of a suspension of macroconidia (to give a final concentration of about $5 \times 10^{4}$ macroconidia per ml medium) in distilled water prepared by harvesting macroconidia from 7-10-d-old cultures grown on agar medium. The flasks were incubated on a rotary shaker (with a throw of $2.5 \mathrm{~cm}$ ) at 200 r.p.m. All cultures we-e grown at $25^{\circ} \mathrm{C}$. The fungus was grown in the presence and absence of edifenphos and exponential-phase $(24 \mathrm{~h})$ biomass was harvested by filtration through muslin.

Incorporation of $\left[{ }^{3} \mathrm{H}\right] \mathrm{GlcNAc}$ into chitin by biomass. Exponential-phase biomass grown in the presence and absence of edifenphos was washed in 2 vols Vogel's medium and incubated at $25^{\circ} \mathrm{C}$ in $25 \mathrm{ml}$ Vogel's medium containing $\left[{ }^{3} \mathrm{H}\right] \mathrm{GlcNAc}\left(0.08 \mu \mathrm{Ci} \mathrm{ml}^{-1} ; 2.96 \mathrm{kBq} \mathrm{ml}^{-1}\right)$ in the presence and absence of edifenphos. Control cultures were treated with $5 \%(\mathrm{v} / \mathrm{v})$ trichloracetic acid (TCA; final concentration) prior to being suspended in Vogel's medium containing $\left[{ }^{3} \mathrm{H}\right]$ GlcNAc. All treatments were incubated at $25^{\circ} \mathrm{C}$ for $30 \mathrm{~min}$ on a rotary shaker (200 r.p.m.) Growth was then stopped by the addition of TCA to give a final concentration in the culture of $5 \%(\mathrm{v} / \mathrm{v})$. Four replicate $2 \mathrm{ml}$ samples were taken from each flask, filtered through Whatman no.l filter papers, and washed with 3 vols distilled water. The biomass and filters were then added to scintillation vials containing $4 \mathrm{ml}$ volumes of scintillation fluid (Optiphase, 'Hisafell') and their radioactivity measured using a Packard Tricarb 1500 liquid scintillation analyser. The residual culture $(17 \mathrm{ml}$ culture + added TCA $)$ in each flask was used for dry weight determinations.

To confirm that $\left[{ }^{3} \mathrm{H}\right]$ GlcNAc was incorporated into chitin, exponential-phase biomass was incubated with the precursor for 30 min as described above. Following incubation, the biomass was treated with TCA (see above) and $5 \mathrm{ml}$ volumes of the suspension were homogenized in a Griffin homogenizer and then centrifuged at $1500 \mathrm{~g}$ for $10 \mathrm{~min}$. The supernatant was removed and the residue was treated for $20 \mathrm{~h}$ in $6 \mathrm{M}-\mathrm{HCl}$ at $25^{\circ} \mathrm{C}$; or for $20 \mathrm{~h}$ in $2 \mathrm{mg}$ chitinase $\mathrm{ml}^{-1} / 50 \mathrm{~mm}$ potassium phosphate buffer at $\mathrm{pH} 6.0$ and $25^{\circ} \mathrm{C}$; or for $20 \mathrm{~h}$ in $1 \mathrm{M}$ acetic acid at $55^{\circ} \mathrm{C}$; or for $20 \mathrm{~h}$ in $2 \mathrm{mg}$ boiled chitinase $\mathrm{ml}^{-1} / 50 \mathrm{mM}$ potassium phosphate buffer at $\mathrm{pH} 6.0$ and $25^{\circ} \mathrm{C}$. After incubation, the reaction mixtures were centrifuged at $1500 \mathrm{~g}$ for $10 \mathrm{~min}$. The residues were collected on $0.2 \mu \mathrm{m}$ Millipore filters and washed with $5 \mathrm{ml}$ distilled water. The filters were then transferred to scintillation vials and $4 \mathrm{ml}$ of scintillation fluid was added to each. The radioactivity of the samples was then measured as described above. The remaining parts of the above cultures were used for dry weight determinations.

Separation of chitin, diacetylchitobiose and UDP-GIcNAc by TLC. The contents of tubes used for assays of membrane-bound chitin synthase were applied to silica gel plates $\left(60 \mathrm{~F}_{254}\right.$, Merck, BDH) together with two $20 \mu \mathrm{l}$ volumes of $50 \%(\mathrm{v} / \mathrm{v})$ aqueous ethanol used to wash out the tubes. The plates were developed in propan-1-ol/water/ammonia $(70: 30: 1$, by vol.) and dried at room temperature. Areas on the plates which corresponded to chitin, diacetylchitobiose and UDP-GlcNAc (Gooday, 1973, as modified by Humphreys, 1984) were visualized by UV illumination, scraped into scintillation vials containing $4 \mathrm{ml}$ scintillation fluid and their radioactivity measured.

Activity of membrane-bound and solubilized chitin synthase. Exponential-phase biomass grown in the presence and absence of edifenphos was washed with buffer ( $50 \mathrm{mM}-\mathrm{MES}, 10 \mathrm{mM}-\mathrm{MgCl}_{2}, 1 \mathrm{~mm}$-EDTA) at pH 6.5 and membrane-bound chitin synthase was extracted using the method of Vermeulen \& Wessels (1983) and stored at $-70^{\circ} \mathrm{C}$. 'Solubilized' chitin synthase was prepared from membrane-bound chitin synthase by treating the preparations with $1 \mathrm{mg}$ digitonin $\mathrm{ml}^{-1}$ as described by Adams \& Gooday (1980). A modification of the method of Adams \& Gooday (1980) was used to assay chitin synthase activity in both preparations. The standard reaction mixture consisted of $10 \mu \mathrm{l}$ of the enzyme preparation, $35 \mu \mathrm{l}$ of buffer $\left(50 \mathrm{mM}-\mathrm{MES}, 10 \mathrm{mM}-\mathrm{MgCl}_{2}, 1\right.$ mM-EDTA, final concentrations at $\mathrm{pH} 6.5)$ and $5 \mu \mathrm{l}$ of substrate $(250$ mM-GlcNAc and $6 \mathrm{~mm}$-UDP-[ $\left.{ }^{14} \mathrm{C}\right]$ GlcNAc containing $13.75 \mathrm{nCi}$ [509 $\mathrm{Bq}])$. The mixture was incubated at $30^{\circ} \mathrm{C}$ for $30 \mathrm{~min}$ and the reaction was stopped by heating at $100^{\circ} \mathrm{C}$ for $2 \mathrm{~min}$. The reaction mixture was then filtered through a Millipore filter (diameter, $25 \mathrm{~mm}$; pore size, $0.45 \mu \mathrm{m}$ ) that had been presoaked for $30 \mathrm{~min}$ in $20 \mathrm{~mm}-\mathrm{Na}_{4} \mathrm{P}_{2} \mathrm{O}_{7}$ containing $5 \%(\mathrm{w} / \mathrm{v}) \mathrm{TCA}$ and then washed in distilled water. The reaction tubes were washed twice with $50 \mu l 1 \%(w / v)$ Triton X-100 and twice with $2 \mathrm{ml}$ distilled water. The filters were transferred to scintillation vials containing $4 \mathrm{ml}$ volumes of scintillation fluid and counted. The effect of dimyristoylphosphatidylcholine on the activity of digitonin-solubilized chitin synthase was tested by adding $1 \mu \mathrm{l}$ of 0 , 0.1 or $0.5 \mathrm{mg} \mathrm{ml}^{-1}$ of dimyristoylphosphatidylcholine (Sigma) in chloroform/methanol $(2: 1, \mathrm{v} / \mathrm{v})$ to the assay mixture (the solvents were included in the controls and had no effect on chitin synthase activity). In these assays, the reaction mixture contained $5 \mu \mathrm{M}$ of the chitinase inhibitor, Allosamidin. 


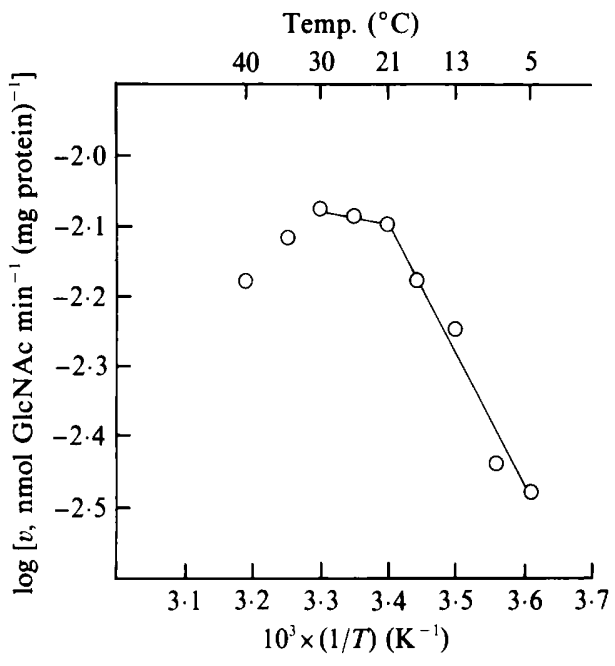

Fig. 1. Arrhenius plot of the effect of temperature on the activity of membrane-bound chitin synthase from $F$. graminearum. Membranebound chitin synthase was extracted from exponential-phase biomass harvested from shake flask cultures grown at $25^{\circ} \mathrm{C}$ as described in Methods.

\section{Results}

\section{Properties of chitin synthase}

Membrane-bound chitin synthase from $F$. graminearum had an apparent temperature optimum of about $30^{\circ} \mathrm{C}$ and maintained $90 \%$ of its initial activity after 6 weeks storage at $-70^{\circ} \mathrm{C}$ (results not shown). Arrhenius plots of the effect of temperature on the activity of membranebound chitin synthase from $F$. graminearum showed a deflection at about $20^{\circ} \mathrm{C}$ (Fig. 1), confirming that the enzyme was membrane-associated (Vermeulen \& Wessels, 1983).

Membrane-bound chitin synthase exhibited optimal activity at $\mathrm{pH} 6.5$, and for incubation periods up to 60 min, preparations at $\mathrm{pH} 6.5$ and $30^{\circ} \mathrm{C}$ incorporated UDP- $\left[{ }^{14} \mathrm{C}\right]$ GlcNAc into chitin at a linear rate (results not shown). Judged by the absence of diacetylchitobiose in the reaction mixture (as indicated by TLC analyses), and by the lack of an effect of $5 \mu \mathrm{M}$-Allosamidin (an inhibitor of chitinase activity; Sakuda et al., 1987) on chitin synthesis, no appreciable degradation of newly formed chitin (by membrane-bound chitinase) occurred at $\mathrm{pH} 6.5$ (a pH which is above the optimum for chitinase activity) during the $30 \mathrm{~min}$ assay period (results not shown). A Lineweaver-Burk plot of reaction velocity against substrate (UDP- $\left[{ }^{14} \mathrm{C}\right] \mathrm{GlcNAc}$ ) concentration gave a $K_{\mathrm{m}}$ value for membrane-bound chitin synthase of about $2.5 \mathrm{~mm}$ and a saturation velocity, $V$, of $3 \times 10^{-3}$ nmol UDP-GlcNAc min $^{-1}$ (mg protein) ${ }^{-1}$ (Fig. 2).

Chitin synthase activity in digitonin-solubilized preparations was variable and was only stabilized when $5 \mu \mathrm{M}$ -

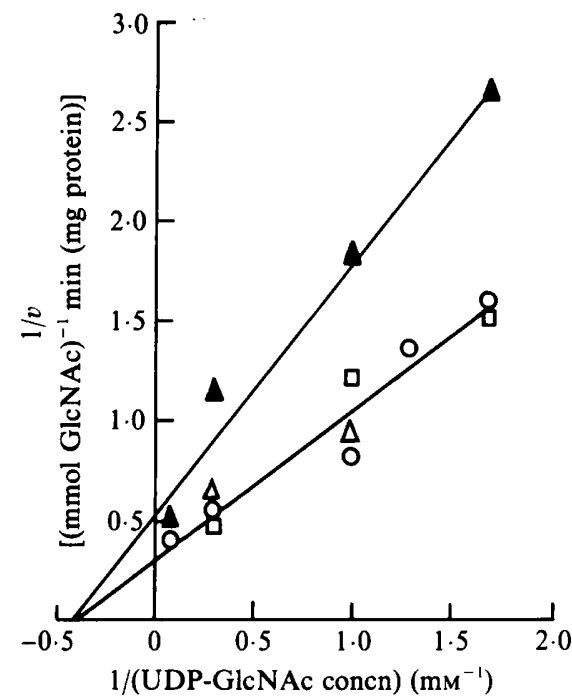

Fig. 2. Lineweaver-Burk plots of the effect of substrate (UDF$\left.\left[{ }^{14} \mathrm{C}\right] \mathrm{GlcNAc}\right)$ concentration on the activity at $\mathrm{pH} 6.5$ and $30^{\circ} \mathrm{C}$ of (1) membrane-bound chitin synthase isolated from exponential-phase biomass of $F$. graminearum grown at $25^{\circ} \mathrm{C}$ in the absence of edifenphos $(\square)$, and (2) membrane-bound chitin synthase isolated from exponential-phase biomass of $F$. graminearum grown at $25^{\circ} \mathrm{C}$ in the presence of $30(\triangle), 60(O)$, or $250(\Delta) \mu \mathrm{M}$-edifenphos. Each result is the mean of four replicates.

Allosamidin was included in the reaction mixture. Addition of $1 \mu \mathrm{l}$ of a $0.5 \mathrm{mg} \mathrm{ml}^{-1}$ dimyristoylphosphatidylcholine solution to the assay mixture resulted in a 3.6fold [from $2.3 \times 10^{-4}$ to $8.2 \times 10^{-4}$ nmol UDP-GlcNAc $\min ^{-1}$ (mg protein $)^{-1}$ ] increase in the activity of digitonin-solubilized chitin synthase.

Inhibition by edifenphos of the activity of membrane-bound chitin synthase. Fig. 3 shows the effect of edifenphos on the in vitro activity of membrane-bound chitin synthase from $F$. graminearum. Edifenphos concentrations up to $25 \mu \mathrm{M}$ had no effect on chitin synthase activity, but between 25 and $145 \mu \mathrm{M}$, chitin synthase activity decreased linearly with fungicide concentration, giving an $\mathrm{IC}_{50}$ (concentration of edifenphos that reduced chitin synthase activity by $50 \%$ ) of $92 \mu \mathrm{M}$. Fig. 4 shows that when edifenphos was added to the reaction mixture, it caused non-competitive inhibition of the activity of membrane-bound chitin synthase, with an apparent $K_{\mathrm{i}}$ of about $50 \mu \mathrm{M}$.

Activity of membrane-bound chitin synthase preparations isolated from $F$. graminearum cultured in the presence and absence of edifenphos

Membrane-bound chitin synthase preparations were isolated from $F$. graminearum cultures which had been grown in the presence and absence of edifenphos. Fig. 2 


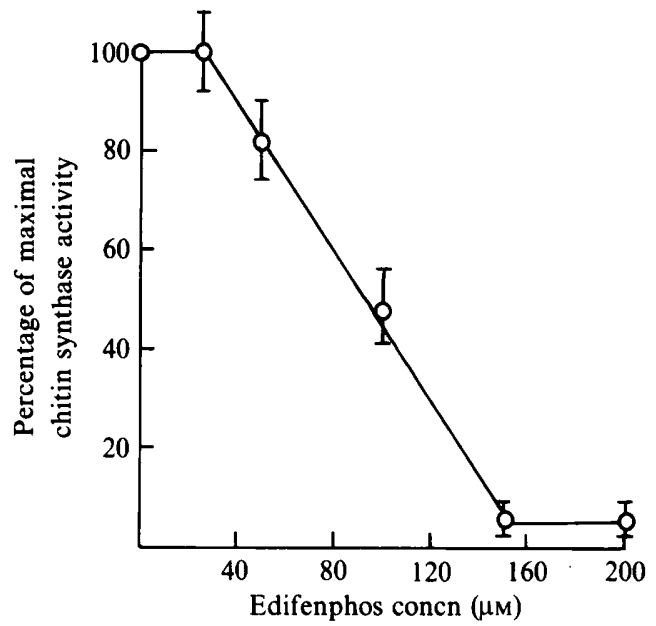

Fig. 3. Effect of edifenphos on the in vitro activity at $\mathrm{pH} 6.5$ and $30^{\circ} \mathrm{C}$ of membrane-bound chitin synthase from exponential-phase biomass of $F$. graminearum grown in the absence of fungicide. In the absence of edifenphos, the preparation had an activity of $5.7 \times 10^{-3} \mathrm{nmol}$ GlcNAc incorporated $\min ^{-1}$ (mg protein $)^{-1}$. Each result is the mean $( \pm \mathbf{S E})$ of four replicates.

shows Lineweaver-Burk plots of the reaction velocities of these preparations at various substrate (UDP$\left.\left[{ }^{14} \mathrm{C}\right] \mathrm{GlcNAc}\right)$ concentrations. Preparations of membrane-bound chitin synthase from cultures of $F$. graminearum grown in the presence of 30 or $60 \mu \mathrm{M}$-edifenphos gave Lineweaver-Burk plots which were indistinguishable from those obtained with preparations from cultures grown in the absence of fungicide (Fig. 2). However, membrane-bound chitin synthase preparations from cultures of $F$. graminearum grown in medium containing $250 \mu \mathrm{M}$-edifenphos had an activity (per $\mathrm{mg}$ protein) which was only about $40 \%$ of that of preparations isolated from cultures grown in the absence of fungicide.

Effect of edifenphos on the incorporation of $\left[{ }^{3} \mathrm{H}\right] \mathrm{GlcNAc}$ into chitin of cultures grown and incubated in the presence and absence of fungicide

When $F$.graminearum was washed and then incubated at $25^{\circ} \mathrm{C}$ in Vogel's medium containing $\left[{ }^{3} \mathrm{H}\right] \mathrm{GlcN}$ Ac, incorporation of radioactivity into chitin occurred at a linear rate for $45 \mathrm{~min}$ (results not shown). The labelled product produced in vivo when $F$. graminearum was incubated with $\left[{ }^{3} \mathrm{H}\right] \mathrm{GlcNAc}$ had the following properties in common with chemically purified chitin: (a) incubating it with $2 \mathrm{mg} \mathrm{ml}^{-1}$ chitinase (but not boiled chitinase) for $20 \mathrm{~h}$ at $25^{\circ} \mathrm{C}$ gave $76 \%$ degradation to GlcNAc, (b) the product was hydrolysed to glucosamine

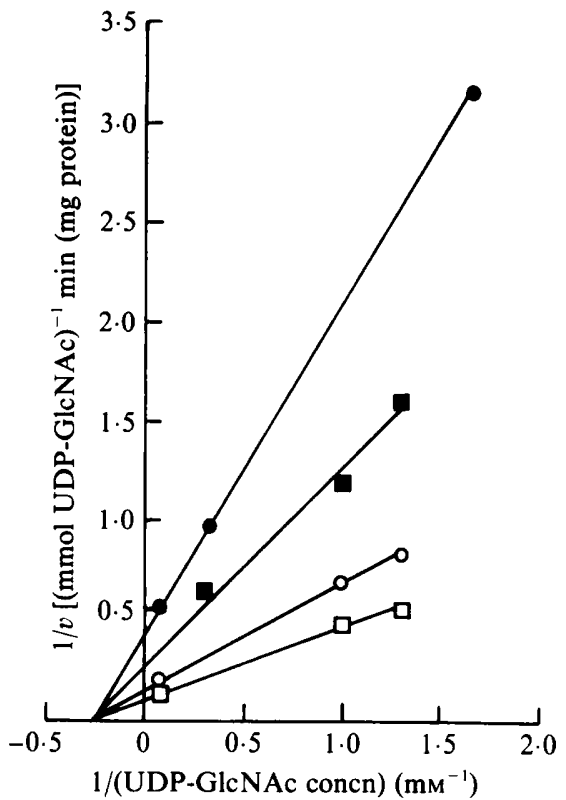

Fig. 4. Lineweaver-Burk plots of the effect of substrate (UDP$\left.\left[{ }^{14} \mathrm{C}\right] \mathrm{GlcNAc}\right)$ concentration on the activity at $\mathrm{pH} 6.5$ and $30^{\circ} \mathrm{C}$ of membrane-bound chitin synthase isolated from exponential-phase biomass of $F$. graminearum grown at $25^{\circ} \mathrm{C}$ and incubated in the presence of $0(\square), 60(O), 100(\square)$, and $120(\bigcirc) \mu \mathrm{M}$-edifenphos. Each result is the mean of four replicates.

when treated with $6 \mathrm{M}-\mathrm{HCl}$, and $(c)$ the product was insoluble in $1 \mathrm{M}$-acetic acid.

Pre-growth of $F$. graminearum in medium containing $80 \mu \mathrm{M}$-edifenphos had no significant $(P>0.05)$ effect on the subsequent incorporation of $\left[{ }^{3} \mathrm{H}\right] \mathrm{GlcN} A \mathrm{c}$ into chitin (Table 1); $80 \mu \mathrm{M}$-edifenphos had no effect on maximum specific growth rate $\mu_{\max }$ (Wiebe et al., 1990), but did affect chitin synthase activity in vitro (Fig. 3). However, addition of $80 \mu \mathrm{M}$-edifenphos to the incubation medium caused a significant $(P<0.05)$ decrease in chitin synthesis (Table 1). This decreased rate of chitin synthesis was not significantly $(P>0.05)$ affected when the biomass was both pre-grown and incubated in the presence of the fungicide (Table 1).

In contrast to the result obtained with $80 \mu \mathrm{M}$ edifenphos, biomass pre-grown in medium containing $250 \mu$ M-edifenphos, washed and suspended in the incubation medium lacking fungicide, had a significantly $(P<0.05)$ lower rate of incorporation of $\left[{ }^{3} \mathrm{H}\right]$ GlcNAc into chitin than control cultures grown and incubated in medium lacking fungicide (Table 1); $250 \mu \mathrm{M}$-edifenphos affects membrane composition but does not affect $\mu_{\max }$ (Wiebe et al., 1990). Chitin synthesis was further decreased when $250 \mu \mathrm{M}$-edifenphos was present in the incubation medium as well as the pre-growth medium. 
Table 1. Effects of edifenphos on the incorporation of $\left[{ }^{3} \mathrm{H}\right] \mathrm{GlcNAc}$ into chitin by $\mathrm{F}$. graminearum biomass pregrown in the presence and absence of fungicide and incubated in vivo in the presence and absence of fungicide

Exponential-phase biomass was harvested from shake flask cultures grown at $25^{\circ} \mathrm{C}$ in the presence or absence of edifenphos, washed and incubated in medium containing $\left[{ }^{3} \mathrm{H}\right] \mathrm{GlcN} A \mathrm{c}$ for $30 \mathrm{~min}$. Rate of $\left[{ }^{3} \mathrm{H}\right] \mathrm{GlcN} A \mathrm{c}$ incorporation is expressed as a percentage of the rate $\left[3.6 \times 10^{-3} \mathrm{nmol}\right.$ GlcNAc $\min ^{-1}\left(\mathrm{~g} \mathrm{dry} \mathrm{wt}^{-1}\right)$ ] of control cultures pre-grown and incubated in the absence of fungicide. Each result is the mean $( \pm \mathrm{SE})$ of four replicates. Figures with the same superscript letter are not significantly different $(P>0.05)$.

\begin{tabular}{ccc}
\hline $\begin{array}{c}\text { Concn of } \\
\text { edifenphos in } \\
\text { pre-growth medium } \\
(\mu \mathrm{M})\end{array}$ & $\begin{array}{c}\text { Concn of } \\
\text { edifenphos in } \\
\text { incubation medium } \\
(\mu \mathrm{M})\end{array}$ & $\begin{array}{c}\text { Rate of incorporation of } \\
{\left[{ }^{3} \mathrm{H}\right] \text { GlcNAc into chitin }} \\
\text { in incubation medium } \\
(\% \text { of control rate })\end{array}$ \\
\hline 80 & 0 & $98 \pm 32^{a}$ \\
0 & 80 & $51 \pm 21^{b}$ \\
80 & 80 & $49 \pm 13^{b}$ \\
250 & 0 & $47 \pm 23^{b}$ \\
0 & 250 & $8 \pm 2^{c}$ \\
250 & 250 & $31 \pm 8^{d}$ \\
\hline
\end{tabular}

\section{Discussion}

The properties ( $\mathrm{pH}$ optimum, apparent temperature optimum and $K_{\mathrm{m}}$ ) of membrane-bound chitin synthase from $F$. graminearum are similar to those for chitin synthase from other fungi (Gooday \& Trinci, 1980). The deflection in the Arrhenius plot (Fig. 1) of the effect of temperature on the activity of membrane-bound chitin synthase is characteristic for membrane-bound enzymes (Vermeulen \& Wessels, 1983), and the temperature at which this deflection occurred $\left(20^{\circ} \mathrm{C}\right)$ was similar to one of the deflections observed for chitin synthase isolated from Schizophyllum commune $\left(12\right.$ and $20^{\circ} \mathrm{C}$; Vermeulen $\&$ Wessels, 1983) and Coprinus cinereus $\left(16\right.$ and $25^{\circ} \mathrm{C}$; Montgomery \& Gooday, 1985). Digitonin-solubilized chitin synthase from $F$. graminearum had a much lower activity than the membrane-bound chitin synthase from which it was prepared. This reduced activity was probably at least partly due to the activity of chitinase in the preparation, because addition of a chitinase inhibitor to the reaction mixture increased chitin synthase activity. The phospholipid requirement of chitin synthase has been demonstrated for preparations from Schizophyllum commune, Coprinus cinereus and Saccharomyces cerevisiae (Vermeulen \& Wessels, 1983; Montgomery \& Gooday, 1985; Humphreys \& Gooday, 1984; Duran \& Cabib, 1978). In these studies, fatty acid chain length and the nature of the polar head group were shown to be important for maximal stimulation of chitin synthase activity. In the present study the activity of digitonin-solubilized chitin synthase from $F$. graminearum was increased 3.6-fold by addition of $1 \mu \mathrm{l}$ of a 0.5 $\mathrm{mg} \mathrm{ml}^{-1}(11.64 \mu \mathrm{M})$ dimyristoylphosphatidylcholine solution to the reaction mixture. This supports previous results demonstrating the requirement for particular lipids for the activity of membrane-associated enzymes. However, even in the presence of Allosamidin and dimyristoylphosphatidylcholine, digitonin-solubilized chitin synthase still only had about $80 \%$ of the activity of the membrane-bound chitin synthase from which it was prepared.

Edifenphos may affect chitin synthase activity (a) directly, $(b)$ indirectly by altering the phospholipid composition of the membrane which in turn modulates chitin synthase activity, or $(c)$ a combination of $(a)$ and (b). At edifenphos concentrations between 60 and $120 \mu \mathrm{M}$ (Fig. 4), non-competitive inhibition of membrane-bound chitin synthase activity in vitro was observed. This result suggests that the inhibitory effect of edifenphos on $F$. graminearum at $60 \mu \mathrm{M}$ and above may be caused by a direct inhibitory effect on chitin synthase activity. Wiebe et al. (1990) showed that concentrations of edifenphos between 41 and $246 \mu \mathrm{M}$ caused a reduction in the mean hyphal extension rate and hyphal growth unit length of $F$. graminearum, but had no effect on specific growth rate. Thus, at these concentrations, edifenphos acted as a paramorphogen (Tatum et al., 1949) rather than as a fungicide. The results obtained here and those of Wiebe et al. (1990) suggest that the paramorphogenic effect of low concentrations of edifenphos on $F$. graminearum could be explained in terms of the fungicide causing direct inhibition of chitin synthase activity. Inhibition of chitin synthase activity would in turn cause a reduction in hyphal extension rate, but, if this was accompanied by increased hyphal branching, it would not necessarily be associated with an inhibition of specific growth rate (Robson et al., 1990). However, caution must be exercised in translating in vitro inhibition data directly to effects in vivo.

As Akatsuka et al. (1977), Kodama et al. (1979) and Ross \& Brady (1985) observed with other fungi, Wiebe $e t$ al. (1990) found that $123 \mu \mathrm{M}$-edifenphos caused a decrease in the phosphatidylcholine content of $F$. graminearum. Growing $F$. graminearum in $250 \mu \mathrm{M}-$ edifenphos (but not in 30 or $60 \mu \mathrm{M}$-edifenphos) caused a reduction in the activity of membrane-bound chitin synthase isolated from the biomass (Fig. 3). Also, pregrowth of $F$. graminearum in medium containing $250 \mu \mathrm{M}$ (but not $80 \mu \mathrm{M}$ ) edifenphos caused a subsequent reduction in $\left[{ }^{3} \mathrm{H}\right]$ GlcNAc incorporation into chitin when the biomass was suspended in medium lacking the fungicide (Table 1). We are currently investigating the hypothesis that pre-growth of $F$. graminearum in high 
concentrations of edifenphos causes changes in membrane composition which in turn affect chitin synthase activity.

We thank the Science and Engineering Research Council for the award of a CASE research studentship to Peter R. Binks and Shell Research Limited, Sittingbourne.

\section{References}

ADAms, D. J. \& Gooday, G. W. (1980). A rapid chitin synthase preparation for the assay of potential fungicides and insecticides. Biotechnology Letters 2, 75-78.

AKatsuka, T., Kodama, O. \& Yameda, H. (1977). A novel mode of action of Kitazin P in Pyricularia oryzae. Agricultural and Biological Chemistry 41, 2111-2112.

BREMNER, J. \& GREENBERG, D. M. (1961). Methyl transferring enzyme system of microsomes in the biosynthesis of lecithin. Biochimica et Biophysica Acta 46, 205-216.

BRILLINGER, G. U. (1979). Metabolic products of microorganisms. 181. Chitin synthase from fungi, a test model for substances with insecticidal properties. Archives of Microbiology 121, 71-74.

Craig, G. D. \& Peberdy, J. F. (1983a). The mode of action of $S$ benzyl-O,O-di-isopropyl phosphorothioate and dichloran on Aspergillus nidulans. Pesticide Science 14, 17-24.

Craig, G. D. \& Peberdy, J. F. (1983b). The effect of $S$-benzyl- $O, O$-diisopropylphosphorothioate (IBP) and dichloran on the total lipid, sterol and phospholipids in Aspergillus nidulans. FEMS Microbiology Letters 18, 11-14.

DE WAARD, M. A. (1974). Mechanisms of action of the organophosphorus fungicide Pyrazophos. Mededelingen Landbouwhogeschool Wageningen. Wageningen: $\mathrm{H}$. Veenman \& Zonen BV.

DURAN, A. \& CABIB, E. (1978). Solubilization and partial purification of yeast chitin synthase. Journal of Biological Chemistry 253, 44194425 .

GoodAy, G. W. (1973). Activity of chitin synthase during the development of the toadstool Coprinus cinereus. Biochemical Society Transactions, 1, 1105-1107.

Gooday, G. W. \& DE Rousset-Hall, A. (1975). Properties of chitin synthase from Coprinus cinereus. Journal of General Microbiology 89, 137-145.

Gooday, G. W. \& TrincI, A. P. J. (1980). Wall structure and biosynthesis in fungi. Symposia of the Society for General Microbiology 30, 207-251.

HUMPHREYS, A. M. (1984). Chitinase activity from Mucor mucedo and its role in hyphal growth. $\mathrm{PhD}$ thesis, University of Aberdeen.
Humphreys, A. M. \& GoOday, G. W. (1984). Phospholipid requirement of microsomal chitinase from Mucor mucedo. Current Microbiology 11, 187-190.

KenNedY, E. P. \& Weiss, S. B. (1956). The function of cytidine coenzymes in the biosynthesis of phospholipids. Journal of Biological Chemistry 222, 193-214.

Kodama, O., Yamada, H. \& AKatsuka, J. (1979). Kitazin P, inhibitor of phosphatidylcholine biosynthesis in Pyricularia oryzae. Agricultural and Biological Chemistry 43, 1719-1725.

Kodama, O., Yamashita, K. \& ARatsuka, J. (1980). Edifenphos, inhibitor of phosphatidylcholine biosynthesis in Pyricularia oryzae. Agricultural and Biological Chemistry 44, 1015-1021.

Leighton, T., Marks, E. \& Leighton, F. (1981). Pesticides: insecticides and fungicides are chitin synthesis inhibitors. Science 213, 905-907.

Maeda, T., Abe, H., KaKiki, K. \& Misato, T. (1970). Studies on the mode of action of organophosphorus fungicide, Kitazin. Part II. Accumulation of an amino sugar derivative from Kitazin-treated mycelia of Pyricularia oryzae. Agricultural and Biological Chemistry 34, 700-709.

Montgomery, G. W. G. \& Gooday, G. W. (1985). Phospholipidenzyme interactions of chitin synthase of Coprinus cinereus. FEMS Microbiology Letters, 27, 29-33.

Robson, G. D., Wiebe, M., KuHN, P. J. \& Trinci, A. P. J. (1990). Inhibitors of phospholipid biosynthesis. In Biochemistry of Cell Walls and Membranes in Fungi, pp. 261-281. Edited by P. J. Kuhn, A. P. J. Trinci, M. W. Goosey \& L. G. Copping. Heidelberg: SpringerVerlag.

Ross, D. C. \& BraDY, U. E. (1985). Organophosphate pesticides and DMSO affect mycelial growth and phosphatidylcholine biosynthesis in an entomopathic fungus. Journal of Entomological Science 20, 287293.

Sakuda, S., Isogai, A., Matsumoto, S. \& Suzuki, A. (1987). Search for microbial insect growth regulators. II. Allosamidin, a novel insect chitinase inhibitor. Journal of Antibiotics 40, 296-300.

ScheINPFLUG, H. \& JUNG, H. F. (1968). Organophosphates for the control of fungal diseases of crops. Pflanzenschutz-Nachrichten 21, 79-91.

Tatum, E. L., Barrat, R. W. \& Cutter, V. M. (1949). Chemical induction of colonial paramorphs in Neurospora and Syncephalastrum. Science 109, 509-511.

TRINCI, A. P. J. (1972). Culture turbidity as a parameter of mould growth. Transactions of the British Mycological Society 58, 467-473.

Vermeulen, C. A. \& Wessels, J. G. H. (1983). Evidence for a phospholipid requirement of chitin synthase in Schizophyllum commune. Current Microbiology 8, 67-71.

VoGEL, H. J. (1956). A convenient growth medium for Neurospora (Medium N). Microbial Genetics Bulletin 13, 42-44.

Wiebe, M. G., Robson, G. D. \& TrinCI, A. P. J. (1990). Edifenphos (Hinosan) reduces hyphal extension, hyphal growth unit length and phosphatidylcholine content of Fusarium graminearum $\mathrm{A} 3 / 5$, but has no effect on specific growth rate. Journal of General Microbiology 136, 979-984. 